\title{
Pengaruh Penggunaan Media Video dan Gambar terhadap Keterampilan Menulis Kembali Isi Cerita Kelas V
}

\author{
Dian Mariya Ulfa $^{1} *$, Sunaryo Soenarto ${ }^{2}$ \\ ${ }^{1}$ Program Studi Pendidikan Dasar, Program Pascasarjana, Universitas Negeri Yogyakarta. Jalan \\ Colombo No.1 Yogyakarta 55281, Indonesia \\ ${ }^{2}$ Jurusan Pendidikan Teknik Elektro, Universitas Negeri Yogyakarta. Jalan Colombo No.1 \\ Yogyakarta 55281, Indonesia \\ * Korespondensi Penulis. Email: dianmariyaulfa@yahoo.co.id \\ Received: 5 January 2016; Revised:6 June 2016; Accepted: 3 January 2017
}

\begin{abstract}
Abstrak
Penelitian ini bertujuan untuk mengetahui (1) pengaruh media video terhadap keterampilan menulis kembali isi cerita siswa kelas V SD pada pembelajaran bahasa Indonesia; (2) pengaruh media gambar terhadap keterampilan menulis kembali isi cerita siswa kelas V SD pada pembelajaran bahasa Indonesia; dan (3) perbedaan pengaruh media video dan gambar terhadap keterampilan menulis kembali isi cerita kelas V SD pada pembelajaran bahasa Indonesia. Jenis penelitian yang digunakan yaitu quasi eksperimen, sedangkan desainnya randomized control-group pretestt-posttestt. Populasi penelitian seluruh siswa kelas V SDN Se-gugus V Kasihan-Bantul, pengambilan sampel dilakukan secara random sampling. Variabel penelitian terdiri dari variabel bebas dan variabel terikat. Teknik pengumpulan data berupa pelaksanan tes unjuk kerja. Instrumen penilaian menulis diukur dengan uji validitas isi dan uji reliabilitas inter-rater. Hasil penelitian menunjukkan bahwa (a) media video berpengaruh positif dan signifikan terhadap keterampilan menulis dengan taraf signifikan $0,000<$ 0,05; (b) media gambar berpengaruh positif dan signifikan terhadap keterampilan menulis dengan taraf signifikan $0,022<0,05$; dan (c) terdapat perbedaan pengaruh media video dan gambar yang signifikan terhadap keterampilan menulis dengan taraf signifikan $0,043<0,05$.
\end{abstract}

Kata Kunci: media video, media gambar, keterampilan menulis kembali isi cerita

\section{The Effectiveness of Implementing Video and Picture Media of Writing Skills in Fifth Grade Students}

\begin{abstract}
The purposes of this study are to find out (1) the effect of video on writing skills in fifth grade students of Elementary School in Indonesian learning, (2) the effect of picture series on writing skills in the fifth grade students of Elementary School in Indonesian learning, (3) the differences of video and picture series on writing skills in the fifth grade students of Elementary School in Indonesian learning. This study used quasi experimental, and the design used randomized control-group pretesttposttestt. The participants of this study were the whole students of the fifth grade of 5 Clusters Kasihan-Bantul Sub-District. The research variables consisted of independent variable and dependent variable. The data were collected using test performance. Writing assessment instruments were measured by content validity and inter-rater reliability tests. The results show that (1) video media gives a positive and significant effect on writing skills in the fifth grade students of Elementary School with sig 0,000 <0,05 (2) picture media gives a positive and significanton effect on writing skills in the fifth grade students of Elementary School with sig 0,022 < 0,05 (3) There is significan different effect between video and picture series on writing skills in the fifth grade students of Elementary School with sig $0,043<0,05$.
\end{abstract}

Keywords: videos, picture series, writing skills to rewrite a story

How to Cite: Ulfah, D., \& Soenarto, S. (2017). Pengaruh penggunaan media video dan gambar terhadap keterampilan menulis kelas V. Jurnal Prima Edukasia, 5(1), 22-34. doi:http://dx.doi.org/10.21831/jpe.v5i1.7693

Permalink/DOI: http://dx.doi.org/10.21831/jpe.v5i1.7693 
Jurnal Prima Edukasia, 5 (1), January 2017 - 23

Dian Mariya Ulfa, Sunaryo Soenarto

\section{Pendahuluan}

Pembelajaran Bahasa Indonesia diarahkan untuk meningkatkan kemampuan siswa dalam berkomunikasi dengan bahasa Indonesia, baik secara lisan maupun tertulis, serta menumbuhkan apresiasi terhadap hasil karya kesastraan. Standar kompetensi pembelajaran Bahasa Indonesia di Sekolah Dasar merupakan kualifikasi minimal siswa yang menggambarkan penguasaan keterampilan berbahasa dan sikap positif terhadap bahasa dan sastra Indonesia. Keterampilan berbahasa mencakup empat komponen yaitu keterampilan menyimak, berbicara, membaca dan menulis (Tarigan, 2008, p.1). Keterampilan bahasa yang perlu diperhatikan yaitu keterampilan menulis. Menulis merupakan salah satu dari empat keterampilan berbahasa produktif yang digunakan sebagai alat komunikasi tidak langsung.

Menulis menurut Iskandarwassid \& Suhendar (2013, p.248) bahwa "aktivitas menulis merupakan suatu bentuk manifestasi kemampuan dan keterampilan berbahasa yang paling akhir dikuasai oleh pembelajar bahasa setelah kemampuan mendengarkan, berbicara dan membaca”. Maka, antara keempat keterampilan berbahasa, menulis dianggap sebagai keterampilan berbahasa yang paling sulit. Hal ini sejalan dengan pernyataan yang dikemukakan (Nurgiyantoro, 2013, p.422) bahwa "dibandingkan tiga kompetensi berbahasa yang lain, kompetensi menulis secara umum boleh dikatakan lebih sulit dikuasai bahkan oleh penutur asli bahasa sekalipun".

Tujuan menulis secara umum meliputi" to inform, to persuade, and to entertan"(Lagan, 2008, p.6). Dijelaskan bahwa tujuan menulis kembali isi cerita pertama menginformasikan, merupakan upaya penulis dalam menginformasikan sesuatu hal yang berkaitan dengan fakta-fakta untuk menjelaskan atau mengajarkan pada pembaca. Tujuan kedua, menulis untuk mempengaruhi merupakan upaya penulis menyakinkan pembaca setuju dengan pandangan terhadap sebuah hal dengan memberikan fakta, namun maksud utamanya adalah untuk membantah atau membuktikan kepada pembaca. Tujuan ketiga untuk menghibur, penulis ingin menghibur dan menyenangkan, serta membuat pembaca merasakan atau mengimajinasikan sebuah cerita.

Menulis merupakan keterampilan yang tidak begitu saja didapat. Menulis membutuhkan latihan yang terus menerus, hal ini sejalan dengan pendapat bahwa keterampilan menulis merupakan keterampilan yang sulit dibandingkan dengan keterampilan berbahasa yang lain. Kegiatan menulis juga dipandang sebuah proses, dalam pelaksanaan pembelajaran menulis dalam menggunakan media guru mengikuti proses tahapan dalam menulis. Tahapan menulis menurut Tompkins \& Hoskisson (1995, p.211) meliputi pra-penulisan, draf, merevisi, mengedit, dan publikasi. Dalam tahapan ini anak perlu mendapat bimbingan dalam memahami dan menguasai cara mentrasfer pikiran kedalam tulisan. Melalui tahapan tersebut siswa dapat mengembangkan kalimat dalam paragraf berdasarkan cerita yang disampaikan melalui media video, gambar dan papan tulis.

Penggunaan media dalam pembelajaran menulis kembali isi cerita didasarkan agar siswa memiliki minat dan ketertarikan yang tinggi terhadap pembelajaran menulis. Salah satu kompetensi yang diajarkan pada kelas V Sekolah Dasar sesuai indikator pembelajaran yaitu keterampilan menulis kembali isi cerita dengan memahami unsur-unsur yang terkandung di dalam cerita. Unsur yang terkandung dalam cerita menurut Tompkins (1994, p.221) meliputi tokoh, alur cerita, latar, tema dan sudut pandang. Namun, unsur cerita yang harus dipahami siswa sesuai indikator pembelajaran kelas V Sekolah Dasar yaitu tokoh beserta wataknya, alur cerita,latar dan tema. Tujuan perlunya siswa memahami unsur-unsur yang terkandung dalam cerita agar siswa dapat menulis kembali isi cerita secara runtut sesuai isi cerita. Selain itu dalam menulis kembali isi cerita siswa juga perlu memperhatikan penggunaan bahasa yang baik dan benar.

Penelitian ini membutuhkan data berupa skor pretest dan posttest untuk mengetahui perbedaan dan seberapa besar persentase pengaruh penggunaan media video, gambar dan papan tulis terhadap keterampilan menulis. Data skor keterampilan menulis diperoleh melalui tes unjuk kerja. Dilakukannya tes menulis untuk mengetahui tingkat kemampuan siswa dalam menuangkan ide, gagasan, dan mengenahi tata tulis dalam menuliskan kembali isi cerita dengan menggunakan bahasa sendiri. Oleh karena itu, guru perlu memilih teknik penilaian yang tepat untuk memperkecil kadar subjektivitas dalam melakukan penyekoran tes menulis. Menurut Iskandarwassid \& Suhendar (2013, p.250) "penilaian terhadap sebuah karangan bebas mempunyai kelemahan pokok yaitu rendahnya kadar objektivitas". 


\section{Jurnal Prima Edukasia, 5 (1), January 2017 - 24}

Dian Mariya Ulfa, Sunaryo Soenarto

Berkaitan dengan aspek penilaian tes menulis kembali isi cerita dalam penelitian yang dilakukan diadaptasi dari Zulela (2013, p. 123) yang disesuaikan kemampuan siswa kelas V Sekolah Dasar meliputi: (1) Isi/gagasan, (2) organisasi, (3) kebahasaan, dan (4) tata tulis. Berkaitan dengan aspek isi/gagasan siswa dapat mengungkapkan isi cerita dengan jelas, logis, mudah dipahami dan sesuai dengan pokok cerita asli. Aspek organisasi dimaksudkan dalam menulis kembali isi cerita gagasan terorganisasi dengan jelas sesuai dengan isi cerita dan alur cerita yang lengkap. Aspek kebahasaan berkaitan dengan penilaian aspek menulis kembali isi cerita meliputi pemakaian bentuk kata, susunan frase, susunan kalimat yang baik, bervariasi dan mudah dipahami. Aspek tata tulis berkaitan dengan penggunaan tanda baca, penulisan huruf, dan pemakaian huruf kapital yang tepat. Aspek penilaian tes menulis, maka dijadikan sebagai pedoman dalam menilai hasil tes menulis siswa.

Proses pembelajaran keterampilan menulis dapat berjalan dengan baik dan sesuai harapan apabila pelaksanaannya memperhatikan komponen pembelajaran. Komponen pembelajaran tersebut meliputi guru yang kreatif, siswa yang proaktif, tujuan pembelajaran yang disesuaikan dengan perkembangan, bahan pembelajaran yang beraneka ragam, strategi atau pun metode pembelajaran yang variatif, media pembelajaran yang menyenangkan dan evaluasi pembelajaran yang tepat. Beberapa komponen tersebut yang memiliki peranan penting dalam menentukan proses pembelajaran adalah guru. Guru dituntut mampu mengembangkan kreativitas dalam mengajar serta mampu memilih media pembelajaran yang tepat sebagai alat bantu atau sarana dalam menyampaikan materi. Penggunaan media pembelajaran disesuaikan dengan materi pelajaran dan karakteristik siswa agar tujuan kompetensi dasar pembelajaran dapat tercapai. Hal ini sesuai dengan pendapat Daryanto (2013, p.18) bahwa" pemilihan media disesuaikan dengan tujuan, materi, serta kemampuan dan karakteristik pembelajar, akan sangat menunjang efisiensi dan efektifitas proses dan hasil pembelajaran"

Keberhasilan suatu proses pembelajaran tidak terlepas dari peran media didalamnya, karena penggunaan media yang tepat mampu meningkatkan kemampuan hasil belajar siswa khususnya dalam keterampilan menulis kembali isi cerita. Pengertian media adalah pengantar pesan dari pengirim ke penerima pesan, dengan demikian media merupakan wahana penyalur informasi belajar atau penyalur pesan (Rusman, 2013, p.159). Maka, penggunaan media dalam pembelajaran dapat membantu guru dalam penyampaian materi agar siswa lebih memahami materi yang disampaikan. Berdasarkan jenisnya media digolongkan dalam kelompok media visual, audio, audiovisual dan multimedia (Gintings, 2010, p. 141).

Adapun media yang digunakan pada penelitian yaitu kelompok eksperimen I menggunakan media video merupakan media penyaluran pesan dengan memanfaatkan indera pendengaran dan penglihatan. penggunaan media video dapat dijadikan sarana khususnya dalam keterampilan menulis kembali isi cerita. Smaldino, et.al. (2008, p.312) menjelaskan bahwa

Strories can be entertaining and informative. Storytelling is an important skill to develop in students of all ages. Video storytelling allows students to be creative while developing their visual literacy skill, writing skill and video production skilss.

Smaldino menjelaskan kisah cerita bisa menghibur dan informatif. Menceritakan kembali sebuah kisah cerita merupakan salah satu kemampuan penting untuk dikembangkan pada siswa dari seluruh usia. Maka, pembelajaran menulis kembali isi cerita pada siswa di Sekolah Dasar akan membawa dampak positif dengan menyesuaikan isi cerita. Penceritaan kisah cerita lewat video memungkinkan para siswa untuk kreatif sembari mengembangkan kemampuan mereka memahami visual, kemampuan menulis, dan kemampuan memproduksi video".

Media yang digunakan pada kelompok eksperimen II yaitu media gambar. Media gambar merupakan salah satu jenis dari media visual atau dikatakan sebagai media grafis. Pengertian media visual menurut Sanjaya (2010, p.211) yaitu "media yang dapat dilihat saja, tidak mengandung unsur suara". Dari pengertian media menurut Sanjaya dijelaskan bahwa media visual merupakan media yang penyampaian informasi hanya menekankan pada aspek penglihatan saja. Penggunaan media gambar cetak dalam pembelajaran menulis kembali isi cerita dapat membatu siswa dalam mengembangkan imajinasi untuk dituangkan dalam tulisan. Sujana \& Rivai (2011, p.9) menyatakan pendapatnya bahwa "pengajaran akan lebih efektif apabila objek dan kejadian divisualisasikan secara realistik menyerupai keadaan sebenarnya, namun tidaklah berarti 
Jurnal Prima Edukasia, 5 (1), January 2017 - 25

Dian Mariya Ulfa, Sunaryo Soenarto

bahwa media harus selalu menyerupai keadaan sebenarnya". Atas dasar tersebut penggunaan media gambar cetak dapat membantu siswa untuk dapat menumbuhkan minat dalam menulis kembali isi cerita karena siswa merasa mudah dan terbantu dalam menungakan ide cerita yang akan ditulis.

Media yang digunakan kelompok kontrol berupa media konvensional yaitu media papan tulis. Media papan tulis digolongan pada media pajang yang digunakan untuk menyampaikan pesan atau informasi di depan kelompok kecil (Arsyad, 2014, p.42). Dijelaskan bahwa media papan tulis termasuk media panjang yang sederhana, dimana hampir setiap ruang tersedia sebuah papan tulis yang bermanfaat untuk penyampaian sebuah informasi sederhana.

Penelitian dilaksakan atas dasar bahwa media berfungsi mengarahkan siswa untuk memperoleh berbagai pengalaman belajar (Indriana, 2011, p.47). Selain itu, penelitian Carrol, \& Holly (2006, p.281) menjelaskan bahwa penggunaan media video berpengaruh signifikan terhadap kemampuan mendengarkan dan menggunakan kosa kata dalam menulis dibandingkan dengan menggunakan media teks. Berdasarkan penelitian relevan, penggunaan media yang tepat dan sesuai dengan tujuan belajar mampu meningkatkan pengalaman belajar sehingga siswa dapat mencapai hasil belajar yang maksimal. Alasan tersebut sejalan dengan pendapat yang dikemukakan oleh Edgar Dale (Sadiman, 2014, p. 8) berdasarkan gambar kerucut pengalaman, bahwa pengetahuan itu dapat diperoleh melalui pengalaman langsung dan pengalaman tidak langsung. Semakin langsung objek yang dipelajari, maka semakin konkret pengetahuan yang diperoleh, semakin tidak langsung pengetahuan itu diperoleh, maka semakin abstrak pengetahuan siswa. Klasifikasi tersebut dikenal dengan nama kerucut pengalaman (cone of experience) dari Edgar Dale.

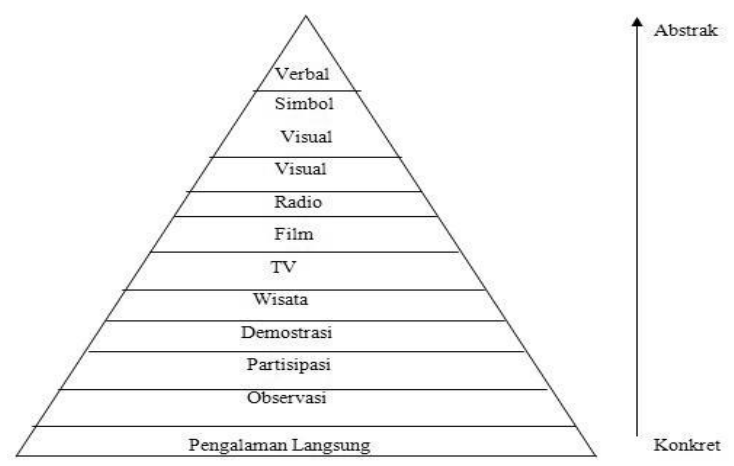

Gambar 1. Kerucut Pengalaman Edgar Dale
Berdasarkan teori kerucut pengalaman Edgar Dale, belajar dengan menggunakan indera ganda yaitu pandang dan dengar akan memberikan keuntungan bagi siswa. Hal tersebut dijelaskan juga oleh Azhar (2014, p.10) bahwa "agar proses belajar mengajar dapat berhasil dengan baik, siswa sebaiknya diajak untuk memanfaatkan semua alat inderanya". Dengan demikian, siswa akan belajar lebih banyak jika dapat memanfaatkan indera pandang dan dengar daripada materi pelajaran disajikan hanya dengan stimulus pandang atau hanya dengan stimulus dengar saja.

Penggunaan media dalam pembelajaran menulis dapat membangkitkan keinginan dan minat yang baru, membangkitkan motivasi dan rangsangan kegiatan belajar, dan bahkan membawa pengaruh psikologis terhadap siswa berkaitan dengan cerita yang diterima. Berdasarkan latar belakang permasalahan yang dihadapi siswa kelas V SDN Se-Gugus V Kasihan Bantul dalam pembelajaran menulis kembali isi cerita yaitu alur cerita yang kurang runtut serta ide cerita yang kurang detail. Selain itu, kesalahan tata tulis baik ejaan, kosa kata dan tanda baca ketika siswa menulis kembali isi cerita. Berdasarkan permasalahan yang dihadapi, hal ini menuntut guru untuk mengajar lebih kreatif dan tidak membosankan. Karena itu, guru memerlukan media pembelajaran sebagai alat bantu dalam mengajar. Adapun pembelajaran Bahasa Indonesia masih berpusat pada guru (teacher centered) saat pembelajaran menulis. Media yang digunakan guru dalam pembelajaran menulis masih kurang bervariasi. Kurangnya penggunaan media yang bervariasi menyebabkan siswa kurang berminat dalam kegiatan menulis kembali isi cerita karena kegiatan pembelajaran yang dilaksanakan selalu monoton.

Tujuan penelitian ini yaitu untuk mengetahui (1) pengaruh media video terhadap keterampilan menulis siswa kelas V SD; (2) pengaruh media gambar terhadap keterampilan menulis siswa kelas V SD; dan (3) perbedaan pengaruh media video dan gambar terhadap keterampilan menulis siswa kelas V SD. Adapun manfaat penelitian meliputi manfaat teoritis dan manfaat praktis. Manfaat teoritis yaitu hasil penelitian ini dapat dijadikan sebagai bahan masukan dalam pemilihan media pembelajaran yang tepat dan hasil penelitihan dapat dijadikan sebagai bahan acuan bagi penelitian lebih lanjut terutama tentang keterampilan menulis melalui media video dan gambar. Manfaat praktik yaitu 
Jurnal Prima Edukasia, 5 (1), January 2017 - 26

Dian Mariya Ulfa, Sunaryo Soenarto

bagi guru, dapat dijadikan sebagai bahan pertimbangan dalam memilih media pembelajaran yang tepat sesuai dengan materi yang diajarkan. Bagi siswa, dapat menumbuhkan minat menulis sehingga siswa semakin mahir dalam menulis. Bagi sekolah, hasil penelitian memberikan sumbangan yang berharga dalam rangka perbaikan sistem pembelajaran sekolah terutama penggunaan media pembelajaran dalam proses pembelajaran.

\section{Metode}

Penelitian yang dilaksanakan menggunakan pendekatan kuantitatif. Adapun jenis penelitiannya yaitu eksperimen semu (quasi eksperiment). Penelitian ini dilakukan di SDN Se-Gugus V Kecamatan Kasihan-Bantul. Waktu penelitian dilakukan pada semester II Tahun ajaran 2014/2015.

Populasi dalam penelitian ini seluruh siswa kelas V SDN Se-Gugus V Kecamatan Kasihan Bantul tahun ajaran 2014/2015 yang terdiri dari 4 SD Negeri dengan jumlah total 124 siswa dari 5 kelas. Teknik pengambilan sampel dilakukan secara random sampling yang artinya tiap unit dalam sampel mempunyai peluang yang sama untuk dipilih.

Variabel yang ada dalam penelitian ada variabel bebas dan variabel terikat. Variabel bebas (independent variables) merupakan varibelvariabel yang menyebabkan, mempengaruhi atau berefek pada hasil. Variabel terikat (dependent variables) merupakan variabel respon atau variabel kriteria yang diasumsikan mendapat pengaruh dari variabel bebas.

Teknik pengumpulan data dalam penelitian ini menggunakan tes ujuk kerja berupa hasil skor keterampilan menulis kembali isi cerita oleh siswa, sedangkan instrumen penelitian yang dikembangkan yaitu pedoman penilaian tes menulis kembali isi cerita.

Validitas instrumen menggunakan pengujian validitas isi. Pengujian validitas isi dilakukan dengan membandingkan antara isi instrumen dengan materi pelajaran yang diajarkan atau berdasarkan kisi-kisi instrumen tes menulis kembali isi cerita, langkah selanjutnya melalui pengujian dari dosen ahli (expert judgement). Setelah instrumen mendapatkan persetujuan dari dosen ahli dilakukan uji coba untuk mengetahui tingkat reliabilitas instrumen tes. Reliabilitas instrumen menggunakan reliabilitas inter-rater memperhitungkan tingkat reliabilitas dari dua deretan skor yang diperoleh dari dua orang korektor atau penguji, yang masing- masing melakukan penskoran terhadap sejumlah peserta tes yang sama (Djiwandono, 2011, p. 187).

Desain yang digunakan dalam penelitian ini adalah Randomized Control Group PretesttPosttestt Design (Suryabrata, 2013, p.118). Dalam desain ini terdapat tiga kelompok yang dipilih secara acak dan diasumsikan ketiga kelompok memiliki karakteristik yang sama (homogen). Dua kelompok diberi perlakuan (eksperimen), dan satu kelompok dijadikan sebagai kelompok kontrol. Pada ketiga kelompok diberikan tes keterampilan menulis tahap awal (soal dan mekanismenya sama), kemudian diberikan perlakuan khusus untuk kelompok eksperimen, dan akhirnya diberikan tes keterampilan menulis tahap akhir (soal dan mekanismenya sama). Hasil ketiga tes keterampilan menulis tahap akhir dibandingkan atau diuji perbedaannya. Hasil tes menulis tahap awal dan tahap akhir pada masing-masing kelompok juga dibandingkan atau diuji perbedaannya. Jika antara tes keterampilan menulis tahap awal dan tahap akhir pada kelompok eksperimen menunjukkan perbedaan, maka terdapat pengaruh dari perlakuan yang diberikan.

Langkah-langkah penelitian yang dilakukan adalah (1) melakukan prasurvei dan mengajukan perizinan sekolah, (2) pembuatan instrumen, validasi instrumen dan uji coba instrumen, (3) mengadakan koordinasi dengan guru berkaitan dengan pembelajaran keterampilan menulis kembali isi cerita dengan menggunakan media video dan media gambar, (4) melakukan pretest, (5) pemberian perlakuan pada kelompok eksperimen I menggunakan media video dan kelompok eksperimen II menggunakan media gambar, (6) memberikan posttest pada masing-masing kelompok penelitian, dan (7) analisis data.

Teknik Analisis Data dalam penelitian ini menggunakan statistik deskriptif dan statistika inferinsial. Analisis deskriptif digunakan untuk menyajikan data yang telah diperoleh dari hasil pretest dan posttest pada keterampilan menulis isi cerita pada kelompok eksperimen dan kelompok kontrol berupa (mean, standar deviasi, skor minimum dan skor maksimum) akan disajikan dalam bentuk tabel sehingga penyajian data akan mudah dipahami. Analisis inferensial digunakan digunakan untuk menguji parameter populasi melalui statistik, atau menguji ukuran populasi melalui data sampel.

Teknik statistik yang digunakan dalam penelitian ini adalah teknik Analisis Varians 
satu jalur. Hasil perhitungan uji Anava dinyatakan dengan nilai $F$. Jika hasil anava menunjukkan $F_{\text {hitung }}>F_{\text {tabel }}$, yaitu Ho ditolak yang artinya ada perbedaan yang signifikan ketiga kelompok, maka dilanjutkan uji LSD untuk mengetahui masing-masing pengaruh perbedaan penggunaan media setiap kelompok. Analisis inferinsial dalam penelitian ini menggunakan bantuan perhitungan dengan SPSS 22.

Dalam teknik analisis Anava, data harus memenuhi kriteria yaitu (1) uji normalitas, uji ini dikenakan pada hasil tes keterampilan menulis tahap awal dan akhir untuk kelompok eksperimen dan kelompok kontrol untuk mengetahui bahwa hasil belajar awal dan akhir siswa sesudah perlakuan yang diambil pada masing-masing kelas berdistribusi normal. Uji normalitas ini dilakukan dengan menggunakan uji Kolmogorof-Smirnov, data berdistribusi normal jika signifikansi > 0,05 (2) uji homogenitas, uji kesamaan varians (homogenitas) bertujuan untuk mengetahui apakah sampel berasal dari populasi yang homogen. Uji homogenitas ini dilakukan terhadap hasil keterampilan menulis tahap awal kelompok kelas kontrol. Pengujian homogenitas dilakukan dengan uji Levene statistic. Data akan homogen jika signifikansi > 0,05. Homogenitas digunakan untuk mengetahui kesamaan varians antara ketiga kelompok. Setelah uji normalitas dan homogenitas, maka dapat dilanjutkan dengan uji Anava satu jalur.

\section{Hasil dan Pembahasan}

Deskripsi Hasil

Sebelum memberikan perlakuan pada kelompok eksperimen, terlebih dahulu diberikan pretest pada kelompok kontrol dan kelompok eksperimen. Pretest bertujuan untuk mengetahui kemampuan awal menulis kembali isi cerita siswa. Setelah itu, kelompok penelitian diadakan uji normalitas untuk melihat apakah semua kelompok penelitian dalam keadaan berdistribusi normal atau tidak dan uji homogenitas untuk melihat apakah semua kelompok penelitian dalam keadaan homogen atau heterogen. Untuk melihat hasilnya, dapat dilihat hasil kedua uji tersebut sebagai berikut.

Tabel 1. Hasil Uji Normalitas Pretest Menulis Kembali Isi Cerita

\begin{tabular}{llll}
\hline Kelompok Penelitian & Statistic & df & Sig. \\
\hline KE I & 0,157 & 23 & 0,147 \\
KE II & 0,176 & 23 & 0,063 \\
KK & 0,175 & 23 & 0,066 \\
\hline
\end{tabular}

Keterangan:

KE I = kelompok eksperimen 1

KE II = kelompok eksperimen 2

$\mathrm{KK} \quad=$ kelompok kontrol

Berdasarkan Tabel 1 hasil uji normal-itas pretest menulis kembali isi cerita menun-jukkan bahwa semua kelompok penelitian berdistribusi normal dengan taraf signifikansi $>0,05$.

Tabel 2. Uji Homogenitas Pretestt Menulis Kembali Isi Cerita

\begin{tabular}{cccc}
\hline Levene Statistic & df1 & df2 & Sig. \\
\hline 0,051 & 2 & 66 & 0,950 \\
\hline
\end{tabular}

Semua kelompok penelitian juga dalam keadaan homogen hal ini ditunjukkan dengan nilai sig > 0,05 yaitu nilai sig sebesar 0,950. Sebelum diadakan perlakuan juga diuji tingkat sebaran siswa pada kelompok penelitian untuk melihat apakah ada perbedaan sebaran siswa antara kelompok eksperimen dan kelompok kontrol. Oleh karena itu, diadakan uji Anava untuk melihat perbedaan. Uji Anava dapat dilihat pada Tabel 3.

Tabel 3. Hasil Uji Anava Pretest Menulis Kembali Isi Cerita

\begin{tabular}{cccccc}
\hline & Sum of Squares & df & Mean Square & F & Sig \\
\hline Between Groups & 0,049 & 2 & 0,024 & 0,202 & 0,818 \\
Within Groups & 8,005 & 66 & 0,121 & & \\
Total & 8,054 & 68 & & & \\
\hline
\end{tabular}

Tabel 4. Hasil Data Pretest dan Posttest

\begin{tabular}{lcccccc}
\hline \multirow{2}{*}{ Ket. } & \multicolumn{3}{c}{ Pretest } & & & Posttest \\
\cline { 2 - 7 } & KE I & KE II & KK & KE I & KE II & KK \\
\hline Mean & 2,54 & 2,48 & 2,51 & 3,05 & 2,83 & 2,57 \\
SD & 0,35 & 0,35 & 0,33 & 0,35 & 0,35 & 0,4 \\
Varians & 0,13 & 0,12 & 0,11 & 0,14 & 0,12 & 0,16 \\
Min & 2,00 & 2,00 & 2,00 & 2,50 & 2,25 & 2,00 \\
Max & 3,25 & 3,25 & 3,00 & 3,75 & 3,50 & 3,25 \\
Siswa & 23 & 23 & 23 & 23 & 23 & 23 \\
\hline
\end{tabular}


Jurnal Prima Edukasia, 5 (1), January 2017 - 28

Dian Mariya Ulfa, Sunaryo Soenarto

Berdasarkan tabel 3 hasil uji anava pada pretest diketahui $\mathrm{F}_{\text {hitung }}$ sebesar 0,202 . Bila nilai $\mathrm{F}_{\text {hitung }}$ dikonfirmasikan dengan $\mathrm{F}_{\text {tabel }}$ dengan taraf signifikansi $0,05(5 \%) \mathrm{dk} 2$ untuk pembi-lang dan 66 untuk penyebut, diperoleh angka $F$ tabel 3,14. Berdasarkan Tabel 3 hasil uji anava diketahui nilai $F_{\text {hitung }}$ lebih kecil dari $F_{\text {tabel }}$ maka dapat disimpulkan bahwa tidak terdapat perbedaan yang signifikan kemampuan awal keterampilan menulis kembali isi cerita peserta didik pada kelompok eksperimen I, kelompok eksperimen II dan kelompok kontrol. Dari hasil uji Anava bahwa semua kelompok dalam keadaan sama, maka penelitian bisa dilanjutkan ke tahap berikutnya yaitu pemberian perlakuan (treatment) pada semua kelompok penelitian dengan menggunakan media pembelajaran.

Kegiatan pembelajaran berjalan seperti biasa dengan menyesuaikan jadwal pembelajaran bahasa Indonesia. Sebelum penelitian dilakukan terlebih dahulu guru diberikan pengarahan berkaitan dengan penggunaan media yang digunakan dalam pembelajaran menulis kembali isi cerita khususnya pada kelompok eksperimen. Untuk kelompok kontrol pembelajaran menulis kembali isi cerita menggunakan media yang biasa digunakan guru yaitu media papan tulis. Adapun pelakuan yang dilakukan sebanyak 5 kali dalam penelitian dengan soal tes sama setiap kegiatan pembelajaran yang membedakan adalah penggunaan media pembelajaran. Setelah perlakuan diberikan pada siswa diikuti dengan pemberian tugas tes menulis yang sama, selanjutnya baik kelompok eksperimen dan kelompok kontrol diberikan posttest dengan soal yang sama. Pemberian posttest bertujuan untuk mengetahui hasil ketrampilan menulis kembali isi cerita setelah adanya pemberian perlakuan.

Pembacaan data hasil prestes dan posttest yang diperoleh akan disajikan dalam bentuk tabel. Hal ini bertujuan untuk mempermudah dalam pembacaan skor hasil pretest maupun posttest, selain itu dpat diketahui perbedaan masing kelompok dari hasil pretest dan posttest.

Berdasarkan Tabel 4 data pretest dan posttest keterampilan menulis kembali isi cerita menjelaskan bahwa, rata-rata kelompok eksperimen I, kelompok eksperimen II dan kelompok kontrol pada pelaksanaan pretest tidak ada perbedaan. Pada hasil posttest rata-rata kelom-pok eksperimen I, kelompok eksperimen II dan kelompok kontrol mengalami peningkatan, namun terdapat perbedaan pada perolehan rata-rata tiap kelompok. Diketahui bahwa rata-rata kenaikan pretest ke posttest masing-masing kelompok yaitu kelompok eksperimen I mengalami peningkatan sebesar 0,51. Kelompok eksperimen I mengalami peningkatan sebesar 0,35. Kelompok kontrol mengalami peningkatan sebesar 0,06. Berdasarkan kenaikan rata-rata setelah dilakukan posttest diketahui bahwa media yang memiliki pengaruh positif terhadap keterampilan menulis yaitu dimulai dari penggunaan media video, media gambar dan media papan tulis.

\section{Hasil Uji Hipotesis}

Uji hipotesis dilakukan setelah uji normalitas dan homogenitas terpenuhi. Hal ini berarti persyaratan parametrik uji hipotesis menggunakan Anova satu jalur yang dilanjutkan dengan uji LSD dapat dilaksanakan dengan syarat Ho ditolak yang artinya terdapat perbedaan antar kelompok penelitian. Hipotesis yang diuji yaitu pertama, media video pengaruh positif dan signifikan terhadap keterampilan menulis siswa kelas V SD. Kedua, media gambar berpengaruh positif dan signifikan terhadap keterampilan menulis siswa kelas V SD. Ketiga, Terdapat perbedaan pengaruh media video dan gambar terhadap keterampilan menulis siswa kelas V SD.

Sebelum dilakukannya uji Anava satu jalur, uji asumsi normalitas dan homogenitas harus terpenuhi. Hasil dari uji normalitas dan homogenitas dapat dilihat dari Tabel 5.

Tabel 5. Hasil Uji Normalitas Posttest Menulis Kembali Isi Cerita

\begin{tabular}{llll}
\hline Kelompok Penelitian & Statistic & df & Sig. \\
\hline KE 1 (media video) & 0,166 & & 0,100 \\
KE 2 (media gambar) & 0,173 & 23 & 0,073 \\
KK (media papan tulis) & 0,176 & 23 & 0,064 \\
\hline
\end{tabular}

Berdasarkan Tabel 5 hasil uji normalitas posttest menulis kembali isi cerita menunjukkan bahwa semua kelompok penelitian berdistribusi normal dengan taraf signifikansi $>0,05$.

Tabel 6. Hasil Uji Homogenitas Posttest Menulis Kembali Isi Cerita

\begin{tabular}{cccc}
\hline Levene Statistic & df1 & df2 & Sig. \\
\hline 0,231 & 2 & 66 & 0,794 \\
\hline
\end{tabular}

Berdasarkan Tabel 6 hasil uji homogenitas posttest menulis kembali isi cerita bahwa semua kelompok penelitian juga dalam keadaan homogen hal ini ditunjukkan dengan nilai sig > 0,05 yaitu nilai sig sebesar 0,794 . Setelah uji normalitas dan homogenitas diketahui, maka 
Jurnal Prima Edukasia, 5 (1), January 2017 - 29

Dian Mariya Ulfa, Sunaryo Soenarto

dapat melakukan pengujian hipotesis pertama, kedua dan ketiga dengan dipaparkannya hasil perhitungan posttest anava satu jalur yang dilanjutkan dengan uji LSD dengan program SPSS 22 disajikan pada Tabel 7.

Berdasarkan hasil analisis variansi anava satu jalur Tabel 7 menunjukkan bahwa nilai $F_{\text {hitung }}$ sebesar 9,750. Bila nilai $F_{\text {hitung }}$ dikonfirmasikan dengan $\mathrm{F}_{\text {tabel }}$ dengan taraf signifikansi $0,05(5 \%)$, dk 2 untuk pembilang dan 66 untuk penyebut, diperoleh $\mathrm{F}_{\text {tabel }} 3$,14. Dengan kriteria ketentuan jika $F_{\text {hitung }}$ lebih kecil dari $F_{\text {tabel }}$ maka $\mathrm{H}_{\mathrm{o}}$ diterima, artinya tidak terdapat perbedaan sig-nifikan. Jika $F_{\text {hitung }}$ lebih besar dari $F_{\text {tabel }}$ maka Ho ditolak artinya terdapat perbedaan signifikan. Dari hasil uji Anava satu jalur diketahui $\mathrm{F}_{\text {hitung }}$ lebih besar dari $\mathrm{F}_{\text {tabel }}$ maka $\mathrm{H}_{\mathrm{o}}$ ditolak sehingga dapat disimpulkan bahwa ada perbedaan yang signifikan antara penggunaan media video, gambar dan papan tulis terhadap keterampilan menulis siswa kelas V SD. Selanjutnya, untuk mengetahui media mana yang lebih berpengaruh positif dan signifikan dari ketiga media pembelajaran tersebut, maka dilanjutkan dengan uji LSD yang hasilnya terdapat pada Tabel 8 .

\section{Uji Hipotesis Pertama}

Uji hipotesis yang pertama adalah "media video berpengaruh positif dan signifikan terhadap keterampilan menulis siswa kelas V SD". Kriteria pengujian adalah Ho diterima jika nilai signifikansi > 0,05 dan Ho ditolak jika nilai signifikansi $<0,05$.

Berdasarkan Tabel 8, secara keseluruhan hasil perhitungan dengan uji LSD tentang adanya perbedaan yang signifikan dalam kete- rampilan menulis antara kelompok eksperimen I menggunakan media video dengan kelompok kontrol menggunakan media papan tulis diperoleh probabilitas sebesar sebesar 0,000 lebih kecil dari taraf signifikansi yang ditetapkan yaitu 0,05 maka Ho ditolak, sehingga dapat disimpulkan bahwa terdapat perbedaan yang signifikan penggunaan media video dan media konvensional terhadap keterampilan menulis kembali isi cerita siswa kelas V Sekolah Dasar.

Untuk menentukan apakah media video memiliki pengaruh yang lebih baik, maka perlu melihat Tabel 8 tentang perbandingan batas atas dan batas bawah kelompok eksperimen I dengan kelompok kontrol. Apabila batas atas dan batas bawah kelompok eksperimen I terhadap kelompok kontrol lebih besar dari batas atas dan batas bawah kelas kontrol terhadap kelas eksperimen I, maka dapat disimpulkan bahwa media video memiliki pengaruh yang lebih baik dibandingkan dengan media konvensional (papan tulis). Batas bawah konfidensi kelas eksperimen I terhadap kelas kontrol bernilai positif sebesar 0,2678 dan batas atas bernilai positif sebesar 0,7104, sedangkan batas bawah dan batas atas konfidensi kelas kontrol terhadap kelas eksperimen I bernilai negatif yaitu 0,7104 dan $-0,278$. Dapat disimpulkan bahwa batas atas dan batas bawah kelompok eksperimen I terhadap kelompok kontrol lebih besar dari batas atas dan batas bawah kelompok kontrol terhadap kelompok eksperimen I. Dengan demikian, pembelajaran menulis kembali isi cerita menggunakan media video memiliki pengaruh yang lebih baik dibandingkan menggunakan media konvensional (papan tulis).

Tabel 7. Hasil Uji Anava Satu Jalur Posttest Menulis Kembali Isi Cerita

\begin{tabular}{cccccc}
\hline & Sum of Squares & df & Mean Square & F & Sig \\
\hline Between Groups & 2,755 & 2 & 1,378 & 9,750 & 0,000 \\
Within Groups & 9,326 & 66 & 0,141 & & \\
Total & 12,082 & 68 & & & \\
\hline
\end{tabular}

Tabel 8. Hasil Uji LSD

\begin{tabular}{|c|c|c|c|c|c|c|}
\hline \multicolumn{7}{|c|}{ Multiple Comparisons } \\
\hline \multicolumn{7}{|c|}{ Dependent Variable:Posttest } \\
\hline \multirow{2}{*}{ (I) Media } & \multirow{2}{*}{ (J) Media } & \multirow{2}{*}{ Mean Difference (I-J) } & \multirow{2}{*}{ Std. Error } & \multirow{2}{*}{ Sig. } & \multicolumn{2}{|c|}{ 95\% Confidence Interval } \\
\hline & & & & & Lower Bound & Upper Bound \\
\hline \multirow[t]{2}{*}{ LSD Video } & Gambar & 0,22826 & 0,11085 & 0,043 & 0,0069 & 0,4496 \\
\hline & konvensional & 0,48913 & 0,11085 & 0,000 & 0,2678 & 0,7104 \\
\hline \multirow[t]{2}{*}{ Gambar } & Video & $-0,22826$ & 0,11085 & 0,043 & $-0,4496$ & $-0,0069$ \\
\hline & konvensional & 0,26087 & 0,11085 & 0,022 & 0,0396 & 0,4822 \\
\hline \multirow[t]{2}{*}{ konvensional } & Video & $-0,48913$ & 0,11085 & 0,000 & $-0,7104$ & $-0,2678$ \\
\hline & Gambar & $-0,26087$ & 0,11085 & 0,022 & $-0,4822$ & $-0,0396$ \\
\hline
\end{tabular}

*. The mean difference is significant at the 0.05 level. 
Jurnal Prima Edukasia, 5 (1), January 2017 - 30

Dian Mariya Ulfa, Sunaryo Soenarto

Selain itu diketahui kelompok eksperimen I mengalami peningkatan rata-rata setelah mendapatkan perlakuan penggunaan media video dalam keterampilan menulis kembali isi cerita sebesar 0,51. Dari hasil uji Anava dan LSD dapat diketahui bahwa media video berpengaruh positif dan signifikan terhadap keterampilan menulis siswa kelas V SDN Se-gugus V Kecamatan Kasihan-Bantul pada pembelajaran Bahasa Indonesia.

\section{Hipotesis Kedua}

Uji hipotesis yang kedua adalah "media gambar berpengaruh positif dan signifikan terhadap keterampilan menulis siswa kelas $\mathrm{V}$ SD". Kriteria pengujian adalah Ho diterima jika nilai signifikansi $>0,05$ dan Ho ditolak jika nilai signifikansi $<0,05$.

Berdasarkan Tabel 8, secara keseluruhan hasil perhitungan dengan uji LSD tentang adanya perbedaan yang signifikan dalam keterampilan menulis antara kelompok eksperimen II menggunakan media gambar dengan kelompok kontrol menggunakan media papan tulis diperoleh probabilitas sebesar 0,022 lebih kecil dari taraf signifikansi yang ditetapkan yaitu 0,05 maka Ho ditolak, sehingga dapat disimpulkan bahwa terdapat perbedaan yang signifikan penggunaan media gambar dan konvensional terhadap keterampilan menulis kembali isi cerita siswa kelas V Sekolah Dasar.

Untuk menentukan apakah media gambar memiliki pengaruh yang lebih baik maka perlu melihat tabel 8 tentang perbandingan batas atas dan batas bawah kelompok eksperimen II dengan kelompok kontrol. Apabila batas atas dan batas bawah kelompok eksperimen II terhadap kelompok kontrol lebih besar daripada batas atas dan batas bawah kelas kontrol terhadap kelas eksperimen II, maka dapat disimpulkan bahwa media gambar memiliki pengaruh yang lebih baik dibandingkan dengan media konvensional (papan tulis). Batas bawah konfidensi kelas eksperimen II terhadap kelas kontrol bernilai positif sebesar 0,0396 dan batas atas bernilai positif sebesar 0,4822 , sedangkan batas bawah dan batas atas konfidensi kelas kontrol terhadap kelas eksperimen II bernilai negatif yaitu $-0,4822$ dan $-0,0396$. Dapat disimpulkan bahwa batas atas dan batas bawah kelompok eksperimen II terhadap kelompok kontrol lebih besar daripada batas atas dan batas bawah kelompok kontrol terhadap kelompok eksperimen II. Dengan demikian, pembelajaran menulis kembali isi cerita menggunakan media gambar memiliki pengaruh yang lebih baik dibandingkan menggunakan media konvensional (papan tulis).

Selain itu diketahui kelompok eksperimen II mengalami peningkatan rata-rata setelah mendapatkan perlakuan penggunaan media gambar dalam keterampilan menulis kembali isi cerita sebesar 0,35. Dari hasil uji Anava dan LSD dapat diketahui bahwa media gambar berpengaruh positif dan signifikan terhadap keterampilan menulis siswa kelas V SDN Segugus V Kecamatan Kasihan-Bantul pada pembelajaran Bahasa Indonesia.

\section{Hipotesis Ketiga}

Uji hipotesis yang kedua adalah "terdapat perbedaan pengaruh media video dan gambar yang signifikan terhadap keterampilan menulis siswa kelas V SD”. Kriteria pengujian adalah Ho diterima jika nilai signifikansi $>0,05$ dan Ho ditolak jika nilai signifikansi < 0,05.

Berdasarkan Tabel 8, secara keseluruhan hasil perhitungan dengan uji LSD tentang adanya perbedaan yang signifikan dalam keterampilan menulis antara kelompok eksperimen I menggunakan media vedio dengan kelompok eksperimen II menggunakan media gambar diperoleh probabilitas probabilitas sebesar 0,043 lebih kecil dari taraf signifikansi yang ditetapkan yaitu 0,05 maka Ho ditolak, sehingga dapat disimpulkan bahwa terdapat perbedaan penggunaan media video dan media gambar terhadap keterampilan menulis kembali isi cerita siswa kelas V Sekolah Dasar.

Untuk menentukan apakah penggunaan media video memiliki pengaruh yang lebih baik dibandingkan penggunaan media gambar maka perlu melihat Tabel 8 tentang perbandingan batas atas dan batas bawah kelompok eksperimen I dengan kelompok eksperimen II. Apabila batas atas dan batas bawah kelompok eksperimen I terhadap kelompok eksperimen II lebih besar dari batas atas dan batas bawah kelas eksperimen II terhadap kelas eksperimen I, maka dapat disimpulkan bahwa media video memiliki pengaruh yang lebih baik diban-dingkan dengan media gambar. Batas bawah konfidensi kelas eksperimen I terhadap kelas eksperimen II bernilai positif sebesar 0,0069 dan batas atas bernilai positif sebesar 0,4496 sedangkan batas bawah dan batas atas konfidensi kelas eksperimen II terhadap kelas eksperimen I bernilai negatif yaitu $-0,4496$ dan $-0,0069$. Dapat disimpulkan bahwa batas atas dan batas bawah kelompok eksperimen I terhadap kelompok 
Jurnal Prima Edukasia, 5 (1), January 2017 - 31

Dian Mariya Ulfa, Sunaryo Soenarto

eksperimen II lebih besar dari pada batas atas dan batas bawah kelompok eksperimen II terhadap kelompok eksperimen I. Dengan demikian, pembelajaran menulis kem-bali isi cerita menggunakan media video memiliki pengaruh yang lebih baik dibandingkan menggunakan media gambar.

\section{Pembahasan Hasil Penelitian}

Pembelajaran bahasa Indonesia keterampilan menulis merupakan salah satu keterampilan yang lebih sulit dibandingkan tiga keterampilan berbahasa lain bahkan oleh penutur asli bahasa yang bersangkutan sekalipun (Nurgiyantoro, 2013, p.442). Maka, untuk mahir dalam keterampilan menulis siswa dibutuhkan banyak praktek dan latihan, selain itu dibutuhkan penggunaan media pembelajaran yang tepat untuk menumbuhkan minat terhadap keterampilan menulis. Hal ini disebabkan, kurangnya rasa suka siswa terhadap aktivitas menulis yang akan berakibat kurang maksimalnya hasil yang diperoleh. Menulis yang baik diperlukan penguasaan meliputi unsur kebahasaan dan unsur diluar bahasa itu yang meliputi aspek yang ada dalam cerita, sehingga kompetensi menulis begitu sulit dikuasi oleh siswa khususnya kelas V Sekolah Dasar dalam pembelajaran menulis kembali isi cerita.

Pembelajaran bahasa Indonesia khususnya keterampilan menulis di Sekolah Dasar selama ini dianggap oleh siswa sebagai pembelajaran yang membosankan. Siswa memiliki rasa bosan ketika guru akan mengajarkan kompetensi menulis. Untuk mengatasi permasalahan tersebut, tentu guru harus memiliki cara khusus agar dapat menumbuhkan minat dan ketertarikan dalam mengikuti pembelajaran menulis disekolah. Salah satu komponen yang mampu meningkatkan keterampilan menulis kembali isi cerita dengan penggunaan media pembelajaran yang tepat.

Media pembelajaran sangat dibutuhkan untuk menunjang minat siswa untuk gemar dan mahir dalam menulis baik cerita fiksi maupun nonfiksi. Pemilihan media pembelajaran sangat diperlukan agar tujuan dari kompetensi dasar dapat tercapai. Secara umum hasil observasi pada kelas eksperimen menunjukkan adanya perubahan dimana siswa menjadi serius dalam mengikuti pembelajaran dan mengerjakan tugas dengan baik meskipun masih terdapat sedikit siswa yang belum menunjukkan perubahan yang mencolok. Pada kelompok kontrol pembelajaran berlangsung seperti biasa.
Penelitian yang dilakukan sebagai upa-ya untuk mengetahui pengaruh penggunaan media video dan gambar terhadap keterampilan menulis siswa kelas V SDN pada pembelajaran Bahasa Indonesia. Hal ini didasarkan pada teori Edgar Dale yang menjelaskan bahwa pengetahuan itu dapat diperoleh melalui pengalaman langsung dan pengalaman tidak langsung. Semakin langsung objek yang dipelajari, maka semakin konkret pengetahuan yang diperoleh, semakin tidak langsung pengetahuan itu diperoleh, maka semakin abstrak pengetahuan siswa (Sadiman, 2014, p.8). Klasifikasi tersebut dikenal dengan nama kerucut pengalaman (cone of experience) dari Edgar Dale. Adapun media yang digunakan merupakan media yang paling dekat dan sering dijumpai oleh siswa yaitu media video, media gambar dan media papan tulis.

Berdasarkan hasil penelitian dijelaskan bahwa (1) media video berpengaruh positif dan signifikan terhadap keterampilan menulis; (2) media gambar berpengaruh positif dan signifikan terhadap keterampilan menulis; dan (3) terdapat perbedaan pengaruh media video dan gambar terhadap keterampilan menulis. Hal ini didasarkan pada uji Anava Satu jalur dilanjutkan dengan uji LSD. Untuk mengetahui pengaruh penggunaan media dalam keterampilan menulis, terlebih dahulu kondisi siswa pada awal pembelajaran adalah sama. Hal ini diketahui dengan memberikan pretest pada semua kelompok baik eksperimen maupun kontrol. Dari hasil pretest yang rata-rata kelompok eksperimen dan kontrol tidak ada perbedaan yang signifikan. Hasil uji anava satu jalur pretest menunjukkan juga bahwa tidak ada perbedaan antara kelompok eksperimen dan kelompok kontrol. Sebelum melakukan uji satu jalur terlebih dahulu dilakukan uji normalitas dan homogenitas, setelah syarat uji normalitas dan homogenitas terpenuhi dapat dilakukan uji anava. Dari uji anava satu jalur menunjukkan nilai sig sebesar 0,818>0,05 Ho diterima, yang artinya tidak terdapat perbedaan kelompok eksperimen dan kontrol, maka penelitian dapat dilakukan.

Penelitian ini bertujuan untuk mengetahui seberapa besar prosentasi pengaruh penggunaan media video, gambar dan konvensional terhadap keterampilan menulis kembali isi cerita kelas V SDN Se-Gugus V Kecamatan Kasihan-Bantul. Setelah siswa diberikan perlakuan sesuai dengan media yang digunakan pada kelompok eksperimen I menggunakan media 
Jurnal Prima Edukasia, 5 (1), January 2017 - 32

Dian Mariya Ulfa, Sunaryo Soenarto

video, kelompok eksperimen II menggunakan media gambar dan kelomopok kontrol menggunakan media konvensional (papan tulis) maka langkah selanjutnya diberikan posttest pada seluruh kelompok eksperimen dan kelompok kontrol. Soal posttest yang diberikan adalah sama. Setelah diperoleh hasil data skor posttest keterampilan menulis kembali isi cerita, data akan diuji dengan uji anava satu jalur. Sebelum dilakukan uji anava satu jalur, asumsi uji normalitas dan homogenitas harus dipenuhi. Diketahui uji normalitas pretest kelompok eksperimen I sebesar 0,147 kelompok eksperimen II sebesar 0,063 dan kelompok kontrol sebesar 0,066 . Berdasarkan nilai sig ketiga kelompok disimpulkan data berberdidtribusi normal karena nilai sig $>0,05$.

Hasil uji homogenitas pretest baik kelompok eksperimen I, kelompok eksperimen II dan kelompok kontrol memiliki varians kelompok yang homogen. Diketahui nilai sig sebesar $0,794>0,05$. Setelah uji normalitas dan homogenitas terpenuhi, langkah selanjutnya dilakukan pengujian anava satu jalur dengan menggunakan bantuan SPSS 22. Diketahui hasil anava satu jalur nilai sig $0,000<0,05$ maka Ho ditolak yang artinya terdapat perbedaan penggunaan media video, gambar dan konvensional. Selain nilai signifikansi, nila $F_{\text {hitung }}$ sebesar 9,750. Bila nilai $F_{\text {hitung }}$ dikonfirmasikan dengan $\mathrm{F}_{\text {tabel }}$ dengan taraf signifikansi $0,05(5 \%)$, dk 2 untuk pembilang dan 66 untuk penyebut, diperoleh $\mathrm{F}_{\text {tabel }} 3,14$. Dari hasil uji Anava satu jalur diketahui $\mathrm{F}_{\text {hitung }}$ lebih besar dari $\mathrm{F}_{\text {tabel }}$ maka $\mathrm{H}_{\mathrm{o}}$ ditolak sehingga dapat disimpulkan bahwa terdapat perbedaan yang signifikan keterampilan menulis kembali isi cerita menggunakan media video, media gambar dan media konvensional pada pembelajaran bahasa Indonesia kelas V Sekolah Dasar. Untuk mengetahui pengaruh perbedaan yang signifikan masingmasing penggunaan media dalam keterampilan menulis kembali isi cerita dengan melakukan uji lanjut LSD.

Pada hipotesis pertama diketahui bahwa media video berpengaruh postif dan signifikan terhadap keterampilan menulis. Hal ini dapat diketahui dari kenaikan rata-rata kelompok eksperimen I setelah menggunakan media video sebesar 0,51. Selain itu, diketahui hasil uji LSD nilai sig $0,000<0,05$ maka Ho ditolak bahwa ada perbedaan yang signifikan pembelajan menulis yang diajar dengan menggunakan media video dibandingkan diajar menggunakan media konvensional. Maka, guru perlu memperhatikan media pembelajaran yang tepat dalam pembelajaran menulis kembali isi cerita yang harus disesuaikan dengan karakteristik siswa. Pembelajaran menulis kembali isi cerita pada kelas kontrol, media yang digunakan adalah papan tulis dimana proses pembelajaran menulis diawali guru membacakan cerita dengan bantuan media papan tulis untuk menulis pokok-pokok cerita. Hal tersebut menyebabkan kurang menumbuhkan minat menulis dan siswa kesulitan menuangkan ide cerita. Penggunaan media video merupakan salah satu upaya untuk memperjelas pemahaman materi pembelajaran berkaitan cerita yang disampaikan. Selain itu, penggunaan media video dalam pembelajaran menulis kembali isi cerita sangat berpengaruh terhadap pemahaman dan kemudahan penyerapan materi pembelajaran serta membantu daya ingat perserta didik dengan jangka lama.

Perbedaan hasil belajar antara penggunaan media video dan konvensional dikarenakan dengan penggunaan media video dalam pembelajaran menulis kembali isi cerita mampu menyajikan materi menjadi lebih menarik, suasana belajar menjadi santai, serta besarnya rasa keingintahuan siswa pada isi cerita yang disaksikan melalui media video. Hal ini berbeda dengan pembelajaran menggunakan media konvensional berupa papan tulis, dimana media papan tulis yang digunakan sebagai alat bantu dalam pembelajaran menulis kembali isi cerita kurang menarik perhatian siswa dan mereka terkesan bosan dengan pembelajaran yang monoton. Sehingga diharapkan guru dapat memilih media pembelajaran yang tepat sesuai dengan karakteristik siswa sehingga hasil belajar dapat tercapai dengan maksimal.

Hasil hipotesis kedua menunjukkan bahwa media gambar berpengaruh positif dan signifikan terhadap keterampilan menulis kembali isi cerita. Hal ini dapat diketahui dari kenaikan rata-rata kelompok eksperimen II setelah menggunakan media gambar sebesar 0,35 . Selain itu, hasil uji LSD diketahui nilai sig $0,022<0,05$ maka Ho ditolak, yang artinya terdapat perbedaan secara signifikan penggunaan media gambar dengan media konvensional dalam keterampilan menulis kembali isi cerita. Selain dari nilai sig, pada tabel uji LSD diketahui terdapat perbedaan yang signifikan mean antara media gambar dan media konvensional yaitu sebesar 0,26. Kesimpulan dari hasil uji LSD penggunaan media gambar berpengaruh lebih baik dibandingkan menggunakan media 
Jurnal Prima Edukasia, 5 (1), January 2017 - 33

Dian Mariya Ulfa, Sunaryo Soenarto

konvensional dalam pembelajaran keterampilan menulis kembali isi cerita.

Berdasarkan hasil analisis data di atas dapat disimpulkan bahwa terdapat perbedaan secara signifikan antara penggunaan media gambar dengan media konvensional dalam pembelajaran menulis kembali isi cerita. Selain itu, terdapat perbedaan hasil skor posttest antara siswa yang diajar menggunakan media gambar dengan menggunakan media konvensional. Perkembangan psikologis seperti faktor usia dapat mempengaruhi kebiasaan belajar siswa dari berbagai tipe. Pada usia (7-11) pada jenjang sekolah dasar secara umum menyukai pembelajaran dari yang sifatnya riil. Salah satu media sebagai alat bantu pembelajaran yang dapat menjebatani kebutuhan tersebut adalah media gambar cetak yang disertai dengan konsep verbal biasanya dilihat/dilakukan siswa. Hal ini dikarenakan media gambar itu menarik, menyediakan gambar nyata unik, memperjelas materi yang bersifat abstrak, mampu mengilustrasikan suatu proses. Media gambar cetak yang digunakan dalam pembelajaran dipilih gambar-gambar yang sesuai dengan pembelajaran berlangsung. Keunggulan inilah yang tidak terdapat pada media papan tulis dimana visual yang ditampilkan dari media papan tulis berupa teks pokok-pokok cerita kalaupun guru jika menggambarkan salah satu adegan dalam cerita dalam papan tulis atau menempelkan salah satu adegan cerita masih kurang menarik.

Hasil hipotesis ketiga menunjukkan bahwa terdapat perbedaan pengaruh media video dan gambar terhadap keterampilan menulis kembali isi cerita. Hal ini didasrkan pada uji LSD bahwa nilai sig 0,043 $<0,05$ maka Ho ditolak, sehingga dapat disimpulkan bahwa terdapat perbedaan yang signifikan keterampilan menulis siswa kelas V Sekolah Dasar pada pembelajaran bahasa Indonesia yang diajar menggunakan media video dibandingkan yang diajar menggunakan media gambar. Selain dari nilai sig, pada tabel uji LSD diketahui terdapat perbedaan yang signifikan rata-rata (mean) antara media video dan media gambar yaitu sebesar 0,228. Kesimpulan dari uji LSD penggunaan media video berpengaruh lebih baik dibandingkan menggunakan media gambar dalam pembelajaran keterampilan menulis kembali isi cerita.

\section{Simpulan}

Berdasarkan hasil penelitian dan pembahasan di atas dapat disimpulkan bahwa bahwa
(1) media video berpengaruh positif dan signifikan terhadap keterampilan menulis pada pembelajaran Bahasa Indonesia kelas V SDN Se-Gugus V Kecamatan Kasihan Bantul dengan kenaikan rata-rata sebesar 0,51 dan taraf signifykan $0,000<0,05 ;$ (2) media gambar berpengaruh positif dan signifikan terhadap keterampilan menulis pada pembelajaran Bahasa Indonesia kelas V SDN Se-Gugus V Kecamatan Kasihan Bantul dengan kenaikan rata-rata sebesar 0,35 dan taraf signifikan 0,022 $<0,05$; dan (3) terdapat perbedaan pengaruh media video dan gambar yang signifikan terhadap keterampilan menulis pada pembelajaran Bahasa Indonesia kelas V SDN Se-Gugus V Kecamatan Kasihan Bantul dengan taraf signifikan $0,043<0,05$.

\section{Daftar Pustaka}

Arsyad, A. (2014). Media pembelajaran. Jakarta: Rajawali Pers.

Carrol, H., \& Holly, Y. (2006). A comparison study of the effects of a story-based video instructional package versus a text-based instructional package in the intermediatelevel foreign language classroom. Calico Journal, Vol.23, 2.

Daryanto. (2013). Media pembelajaran peranannya sangat penting dalam mencapai tujuan pembelajaran. Yogyakarta: Gava Media.

Djiwandono, S. (2011). Tes bahasa pegangan bagi pengajar bahasa. Jakarta: PT Indeks.

Gintings, A. (2010). Esensi praktis belajar \& pembelajaran. Bandung: Humaniora.

Indriana, D. (2011). Ragam alat bantu media pembelajaran.Yogjakarta: Diva Press.

Iskandarwassid \& Sunendar, D. (2013). Strategi pembelajaran bahasa. Bandung: Remaja Rosdakarya.

Langan, J. (2008). Exploring writing: paragraph and essays. New York: McGraw-Hill Companies.

Sadiman, A.S., et.al. (2014). Media pendidikan. Jakarta:Rajawali Pers.

Sanjaya, W. (2010). Strategi pembelajaran berorientasi standar proses pendidikan. Jakarta: Prenada Media Group.

Nurgiyantoro, B. (2013). Penilaian pembelajaran bahasa berbasis kompetensi. Yogyakarta: BPFE Yogyakarta. 


\section{Jurnal Prima Edukasia, 5 (1), January 2017 - 34}

Dian Mariya Ulfa, Sunaryo Soenarto

Pringgawidagda, S. (2002). Strategi penguasaan berbahasa. Yogjakarta: Adicita Karya Nusa.

Rusman. (2013). Belajar dan pembelajaran berbasis komputer: mengembangkan profesionalisme guru abad 21 Jakarta: Alfabeta,cv.

Smaldino, S.E., et.al. (2008). Instructional technology and media for learning $\left(9^{\text {th }} e d.\right)$. New Jersey: Merrill Prentice Hall.

Sudjana, N. \& Rivai, A. (2011). Media pengajaran. Jakarta: Sinar Baru Algensindo.

Suryabrata, S. (2013). Metodologi penelitian. Jakarta: Raja Grafindo Persada.
Tarigan, H. G. (2008). Menulis sebagai suatu ketrampilan berbahasa. Bandung: Angkasa.

Tompkins, G.E. (1994). Teaching writing balancing process and product $\left(2^{\text {rd }} e d\right.$.). New York: Macmillan College publishing company.

Tompkins, G.E., \& Hoskisson, K. (1995). Langguage arts: content and teaching strategies ( $3^{\text {rd }} e d$.). Engelewood, NJ: A Simon \& Schuster Company.

Zuhdi, D. \& Rofi'udin, A. (2002). Pendidikan bahasa dan sastra indonesia di kelas tinggi. Malang: Universitas Negeri Malang Press.

Zulela. (2013). Pembelajaran bahasa indonesia; apresiasi sastra di sekolah dasar. Bandung: PT Remaja Rosdakarya. 